\title{
BRASIL PEREGRINO NA ALEGORIA BARROCA
}

\author{
Maria Francelina Silami Ibrahim Drummond*
}

RESUMO :

Estuda-se no Peregrino da América (1728) articulação de dois planos narrativos - um de moralidade, outro de cenas de costumes na Colônia -, este sendo responsável pelo sucesso do livro. Essa narrativa alegórica é fonte para história da leitura e texto precursor dos primeiros esboços de nação na Literatura Brasileira.

PALAVRAS-CHAVE: alegoria, costume colonial, leitor, nação.

0 Compêndio narrativo do peregrino da América, de Nuno Marques Pereira, editado em 1728, está entre os livros de maior circulação na Colônia. Atesta-o não apenas sua fortuna crítica (Drummond: 2000) como o confirmam estudos recentes que investigaram fontes arquivísticas e cartoriais dos séculos XVIII e XIX no Brasil. (Araújo: 1999)

0 sucesso do Peregrino da América naquela época tem sido equivocadamente analisado pela crítica e historiografia literárias. Tornou-se ponto indiscutível afirmar que este livro foi muito lido no Brasil e em Portugal em função de seu caráter moralista e edificante. Como se tratava de uma época eivada do peso da Cristandade, ainda submetida às normas do Concílio de Trento e a um rigor moralista que vigorava pelo menos em nível discursivo, nada mais fácil do que incluir nessa moldura a interpretação do Peregrino da América. 0 enredo aparentemente colabora para essa conclusão: o livro narra a história de um peregrino que desce da Bahia para Minas, em início do século XVIII, horrorizado com a situação de vícios, crimes e delitos que o diabo, transmigrado da Europa para a América, insuflava os homens a cometer. Sem nome nem procedência declaradas, o andarilho tem o propósito de ajudar a combater aquela situação de miséria imaterial, gerada sobretudo pela * Doutora em Letras: Estudos Literários (Área de concentração: Literatura Comparada), 2000. 


\section{EM TESE}

Belo Horizonte, v. 5, p. I-305, dez. 2002

descoberta do ouro, e a arma de que dispõe nada mais é senão a palavra. Admoesta, aconselha, prega o exemplo sadio e a esperança num reino de justiça e fraternidade. Esta fala é a que denomino primeira narrativa, fundamentada nas Escrituras, nos pensadores da antigüidade clássica, em São Paulo e Orígenes, no cristianismo do século IV, em Agostinho, Gregório Magno, Ambrósio, Tomás de Aquino e ascetas do século XVII. Ela se impõe com força persuasória própria da argumentação conceptista, que joga com extremos e contrastes, encenando situação dual e maniqueísta na qual o homem vislumbra o poder incontestável da ordem divina. No entanto, esse discurso é permeável, deixando à mostra inúmeras contradições da consciência humana atribulada, no limiar do teocentrismo para o antropocentrismo, pelo dilema básico: o homem sente o apelo do carpe diem e a aflição do memento mori. Por isso, a tematização barroca da viagem, elaborada no pensamento de São Paulo e continuada em Agostinho, transparece primeiramente como alegoria maior dessa narrativa que marca o começo histórico (Sussekind, 1990: 7) da ficção no Brasil: o homem tem o destino de ser andarilho nesta terra, a caminho da eternidade. Este sentido da viagem foi recuperado como tema de uma longa tradição literária, incluindo a literatura ibérica dos século XVI e XVII, reaparecendo na literatura brasileira colonial com 0 peregrino predestinado, de Alexandre de Gusmão (1682) e sendo retomada no Peregrino da América, com outras significações. Será viagem pelo Brasil, tomada no sentido do reconhecimento da cultura colonial; e será também uma viagem encenada aos livros.

A primeira narrativa permite vislumbrar elos que unem a literatura colonial a modelos e temas universais e, ao mesmo tempo, oferece subsídios para análise da citação, considerada não apenas referência direta a autores, mas procedimento narrativo amplo que engloba, além da citação propriamente dita, a alusão, colagem, recorrência a textos e apropriação de outros discursos, em elaborado jogo intertextual com objetivo exemplar. Tal narrativa se articula com um segundo nível discursivo que espacializa o enredo na Colônia, recortada em cidades, fazendas, sítios e povoados por onde o peregrino passa e é hospedado.

Nesta segunda narrativa, pode-se apreciar a intenção irônica do narrador em mostrar o interdito e a permissividade da vida no Brasil. Ela se compõe de casos cotidianos sobre comportamento das pessoas, das mais comuns às mais tituladas, 
ocupantes de cargos públicos, civis e eclesiásticos, de maneira que a sociedade colonial parece ali representada. Mostra - aparentemente à revelia do autor/ narrador caracterizado como herdeiro do pensamento jesuítico, leigo inconformado que clama por justiça - o retrato da Colônia captado em seu duro realismo: clero devasso e alheio à tarefa da evangelização, relatos de mancebia e adultério, prostituição de meninas, pactos com o diabo, assassinatos, perfídias, logros, corrupção da justiça, superexploração do trabalho escravo e tantos mais. Essas imagens são construídas como cenas vivas, pequenos enredos de situações da vida cotidiana, detalhadamente, de modo a causar surpresa ao leitor atento à seriedade da primeira narrativa mesmo que esses casos tenham o objetivo de ilustrar e exemplificar a pregação moralista. Não apenas surpreendem mas, cheios de contornos e minúcias, são geralmente engraçados e mordazes.

Entretanto, à medida que foram extraídos do cotidiano colonial - pois o peregrino tem olhar de cronista e se preocupa visivelmente em registrar aspectos da cultura no Brasil - os trechos que compõem a segunda narrativa provavelmente terão contribuído pela preferência de leitura que o Peregrino da América teve no século XVIII. Nessa articulação de dois níveis narrativos tão marcadamente expressos, analiso as potencialidades de leitura e o chamariz do leitor que o livro teria, à sua época, desencadeado.

Se a leitura era hábito rarefeito em meio à maioria iletrada, sabe-se de outro hábito difundido, o da "escuta" da leitura alheia. Alguém lia para o grupo que não conseguia decifrar o código escrito ou não tinha acesso ao livro. Muitos recursos narrativos usados no Peregrino da América, como descrições detalhadas, movimentação de cenas, trocadilhos e justaposição de imagens, sugerem essa possibilidade de texto para se ler em voz alta. Concorreram também para formar o gosto pela leitura literária as cópias manuscritas de livros, caros e inacessíveis, que corriam em muitas mãos, como a transcrição de textos do século XVIII, encontrados por Câmara Cascudo. (Cascudo, 1978: 197). Em Minas dos dias atuais, a prática se mantém, haja vista uma vasta documentação manuscrita, de cunho literário, produzida nas décadas de 50 e 60 e recentemente encontrada em Ouro Preto. Nosso incipiente público leitor ia-se formando nesses diversos caminhos ao encontro do livro, chegando mesmo a 


\section{EM TESE}

Belo Horizonte, v. 5, p. I-305, dez. 2002

existir, não em tempo remotos, mas a mostrar outra prática cultivada, pessoas que sabiam de cor e declamavam narrativas de gosto popular. (Cascudo, 1953: 22).

É provável que a segunda narrativa do Peregrino da América não tenha passado em branco para esse leitor, copista, ouvinte e declamador justamente porque ele se identificava com ela; o narrado era a possibilidade encenada de autoreconhecimento, oportunidade de riso e brincadeira, em contraste com o primeiro nível do discurso que, em certas passagens, chega a ser aterrador.

Esta foi, a meu ver, a cilada irônica em que a crítica e historiografia literárias caíram, ao centrarem o olhar na pregação moral, desconhecendo o segundo aspecto da narrativa na qual entram a parábola, a sátira, o deboche, a descrição da espontaneidade do cotidiano. Desconheceram, por isso, que houve um leitor histórico de cuja existência decorreram as edições que o livro teve no século XVIII e a popularidade de que gozou.

Outra metáfora recorrente no Peregrino da América tem apelo especial como fonte para a história da leitura no Brasil: o narrador empreende uma viagem aos livros e ao conhecimento erudito. A primeira marca dessa intencionalidade conduzir o leitor a livros - está contida na alusão à alegoria do Anjo do Apocalipse que, trazendo um livro às mãos, ordena que ele seja devorado. Diversas vezes o narrador recorre a essa imagem do livro como alimento: "Sabei que os livros também se comem: assim mandou Deus dizer pelo Anjo a S. João" (Pereira, 1988 :v. I, 26) e a ela retorna ao falar de autores ibéricos muito conhecidos à época, como Jerônimo Cortez e seu Lunário perpétuo (1703), guia prático de conhecimentos astrológicos, medicinais, agrícolas ainda hoje lido e por vezes reeditado; Belchior de Santa Cruz Bueñas e a Floresta espanhola; Cervantes, Heitor Pinto, Rodrigues Lobo, Francisco Manoel de Me1o, Amador Arraes, Quevedo e 0livia Sabuco, entre tantos outros. "Homem muito versado nas histórias dos livros sagrados e profanos" ,(Pereira, 1988: v. I, 293), o peregrino transita no jogo irônico entre despojamento material e capacidade para fazer reflexão erudita. A estratégia de escrita é traçada a partir da experiência e de suas leituras; ele cita confiado na memória e evocação de livros, pois, diferentemente do eremita de Petrarca, o peregrino não leva nenhum livro consigo. A esta estilização do narrador sem livros, mas portando a memória deles, corresponde 
o estímulo à leitura e à então chamada instrução pública que também sustentarão, já no século XIX, o ideário romântico de nação. E não é apenas citando autores, mas também visando ao gosto pela leitura que o narrador fala de livros, inventa uma narrativa mesclada de poesia de cunho popular, quadras, cartas, provérbios, trocadilhos e alusões próximas da fábula. Dirige-se ao leitor erudito e tenta atrair atenção do leitor mais comum, o que se formava, embora, como moralista, condene leituras que "ensinam a falar, para pecar". (Pereira, 1988: v. I, 27). Por outro 1ado, o peregrino trabalha com concepções contemporâneas de texto e escrita. Apresentandose como compendiador, ele adota o ponto de vista segundo o qual os textos se retomam, reescrevem e retocam, aludindo à intercomunicação, à intertextualidade. Ao afirmar que "quis seguir alguns autores da melhor nota nesta minha escrita, que também usaram deste modo de escrever em diálogos, e interlocutores," (Pereira, 1988: v. II, 34), está justificando não apenas opção estilística, mas também se situando na tradição literária como leitor dos clássicos, de ascetas e místicos medievais, novelas de cavalaria, de Vieira, Alexandre de Gusmão e Gregório de Matos.

Além da crítica à vida colonial, o Peregrino da América encena uma sociedade em confissão, relatando-se e relatando a vida em minúcias. Ouve-se a fala do dominante e, em certo sentido, a do dominado. Escrito como um longo diálogo no qual o Peregrino conta a viagem ao Tempo (alegorizado num velho), em técnica de flash-back, o livro acolhe, como já referi, inúmeros signos da vida no Brasil, visando a mostrar a complexidade de traços e influências culturais em estágio de multiculturalismo e, nalguns aspectos, de aculturação e sincretismo. Alguns exemplos disso são a caracterização de feitiçaria na cerimônia de candomblé e a descrição trágica do encontro entre o Peregrino e negros trabalhando em dia santificado, sob a desculpa do fazendeiro de que assim agia para evitar que seus escravos se embriagassem, caso tivessem folga para irem à igreja.

Se há falas e ruídos de ricos e pobres, brancos e pretos, padres e civis, mulheres e crianças, há também muitos silêncios, como o do índio, apenas referido três vezes, sem voz : junto de um mineiro como "um índio da terra que o acompanhava fielmente", (Pereira, 1988: v. I, 220); justiçando ladrões que se "atam em uma árvore" (Pereira, 1988: v.I, 270) e vendendo "uma bola de âmbar." (Pereira, 1988: v. I, 274). A presença do negro, em contrapartida, é marcante e só concorre com a do judeu, que 


\section{EM TESE}

Belo Horizonte, v. 5, p. I-305, dez. 2002

o Peregrino não perde de vista para satirizar e responsabilizar por avareza e delação contumazes. Há uma forte tendência de atacar o clero secular, rude e ignorante.

Sem forçar a interpretação no rumo historiográfico colado aos fatos, é possivel identificar insinuações do Peregrino da América a acontecimentos sociais mineiros, como a guerra dos emboabas, em 1709, cujo sinal de possiveis simpatias está implícito na súplica do livro dirigida a Manuel Nunes Viana que fez editar o livro em Lisboa. Realçando a rota Bahia-Minas como percurso da ficção, é sintomático que o autor do Peregrino da América tenha ignorado a força bandeirantista de São Paulo sobre Minas e passado ao largo dos territórios auríferos de Mato Grosso e Goiás, já então descobertos pelos paulistas. Na caracterização da sociedade colonial, ele não expõe o clero regular à sátira, poupando-o de situações vexamosas e evitando apresentá-10 como protagonista de vícios e pecados, em contraste com o clero secular, causticado nas mais diversas ocasiões de delitos e penas. Terá sido mera coincidência com a prática emboaba, tolerante com os frades, muitos dos quais deram suporte à luta? Embora a documentação conhecida não confirme a participação do autor no conflito, é provável que ele tenha conhecido o território das minas e até chegado a Vila Rica.

Alguns argumentos do narrador sugerem aproximações com a realidade social, como sua atenção declarada com o peregrino político (Pereira, 1988: v.I, 37) e não apenas o espiritual; a indignação com o trabalho escravo e as condições em que viviam os negros no Brasil, além dos abusos contra pobres e desamparados, em menção indireta a vícios de colonização. Não há, pois, como ignorar que, embora trabalhe com a metáfora da viagem significando passagem para a vida eterna, 0 narrador, viajante e cronista, vislumbre também o Brasil histórico, em sentido presente (ver) e prospectivo (sonhar com a superação daquele presente de contingências e vícios). Ele quer compreender vendo, observando e registrando e, assim, pela primeira vez, a narrativa de ficção se detém nas maneiras peculiares de vida dos habitantes do Brasil, tomando-as como matéria ficcional. A viagem é, pois, uma sucessão de cenas que enquadram e detalham flagrantes de homens comuns no interior das casas, em roças, caminhos, fazendas, nas ruas de Salvador e em torno das minas de ouro. Esses detalhes compõem pequenos enredos que o narrador ajunta, através do diálogo, construindo uma narrativa de motivos variados. A matéria básica desse 
discurso é o costume no qual o cronista se detém. Ora, buscar o costume talvez seja a forma mais adequada de perceber a cultura, sobretudo quando se considera que 0 "costume é a morada do ser", (Lima Vaz, 1988: 12), o lugar privilegiado da revelação de como somos. E, ao ficcionalizar o costume colonial, o Peregrino da América inaugurava a representação de um Brasil visto através da cultura e não mais, da louvação ufanista da natureza.

Baseado nesse costume e reconhecendo nele virtudes e potencialidades da gente do Brasil - em primazia sobre a terra do Brasil, o narrador insinua uma utopia de comunidade fraterna, tomada como esboço da idéia de nação. Ela provém da reflexão recorrente sobre a vida do homem neste mundo, resultado de sua formação ascética (está nos antigos, nos clássicos, nos medievais, passa pela Renascença e atinge o Barroco), e também decorre na crença pré-romântica no povo, sua cultura e natureza em que vive. 0 olhar do ficcionista localiza esse esboço de nação na cultura colonial fragmentária, híbrida e miscigenada, mostrando a tensão dilemática entre vício e virtude de onde extrai um ethos purificado para sua comunidade idealizada.

Essa idéia de nação se elabora no Peregrino da América na montagem do retrato do Brasi1, com elementos da tradição de representação da terra dos primeiros cronistas; simbolização da cidade, no modelo ascético, e da pátria, nos místicos. A terra será repetidas vezes associada à polaridade paraíso/inferno e está na evocação lírica da paisagem que acolhe e mesmo amedronta o narrador. A cidade tem lastro em precedentes ilustres nos discursos utópicos e, na representação barroca do Peregrino da América, se revela na esperança de reconstrução do Brasil como "empório do mundo". (Pereira, 1988: v. I, 37 ). Já pátria é a aspiração imaterial e fim, resultante da peregrinação bem feita na terra.

A retratos anteriores da Colônia - de Frei Vicente de Salvador, Ambrósio Fernandes Brandão, de Antonil -, o Peregrino da América agregará outros contornos e outras cenas de como vivia e se manifestava o Brasil. Esses retratos ajudarão a compor uma tradição na qual se espelhará a nação imaginada dos românticos. Serão sobretudo ingredientes essenciais do repertório de formação do imaginário social brasileiro. Nele parece viver a nação. 


\section{EM TESE}

Belo Horizonte, v. 5, p. I-305, dez. 2002

0 peregrino alegoriza um Brasil andarilho, mutante, formando-se; visto, pois, em sentido prospectivo. Essa imagem se vincula ao significado de Apocalipse, ou da profecia, revelação das coisas ocultas, especialmente referentes ao futuro. Neste sentido, o olhar do Peregrino é utópico. Por isso, o leitor descobre, no jogo contraditório entre a narrativa de moralidade e a outra sobre o cotidiano do Brasil, um sentido profético do discurso: falar das coisas que vão acontecer.

NOTAS

1. Tomei-o como objeto de estudo na tese de doutoramento em Literatura Comparada, enfocando sobretudo o tema viagem na literatura brasileira, as vias de formação do público leitor na Colônia e a elaboração das primeiras idéias sobre nação entre nós.

2. Citação abundante de textos e autores desde a Antigüidade Clássica, passando por pensadores medievais, místicos e ascetas, renascentistas e barrocos; abordagem da literatura, do livro e da leitura como temas da narrativa.

3. 0 aspecto aterrador da narrativa sugere aproximação de leitura com os manuais de confessores do século XVII e alguns termos de exorcismo.

4. Em 1872, mostrando certa convenção de leitura do Peregrino da América, Varnhagen ainda o recomendava a seminaristas, apontando nele as grandes qualidades do moralista.

5. Houve cinco edições do Peregrino da América no século XVIII: 1728, 1731, 1752, 1760 e 1765.

6. Exemplo importante, entre outros, é a citação da muito lida Imagem da vida cristãa(1572), de Frei Heitor Pinto, tomada como modelo.

7. 0 sabiá, que mais tarde se tornará ave-símbolo do Romantismo, aparece pela primeira vez na literatura brasileira, em contraposição ao rouxinol europeu.

8. Está no capítulo XI do Peregrino da América a primeira representação literária do candomblé na Literatura Brasileira.

9. Ideologemas como esses, cristalizados no imaginário popular, que ainda nutrem o acervo de preconceitos raciais contra negros e mulatos, são temas explorados na narrativa.

10. Cf. documentos 28, 38, 39 e 43 do Códice Costa Matoso.

11. A escravidão é severamente criticada como pecado social contra a justiça.

12. Concepção antecipatória, intuída como comunidade virtuosa e fraterna que é possível à luz do plebiscito de todos os dias, de Ernest Renan, e do conceito performativo de nação, de Homi Babbha que desloca o eixo do estado-nação como espaço que deixou de representar o mundo contemporâneo cada vez mais integrado, para o de temporalidade de uma comunidade imaginada, na expressão de Anderson. 
RÉSUMÉ:

On étude dans le Peregrino da América (1728) l'articulation entre deux plains narratives - un lié à une vision morale; l'autre à la vie de la Colonie.

Cette narration allégorique est une source importante pour l'histoire de la lecture $e$ un texte antecipateur d'un portrait de la nation dans la Littérature brésilienne.

MOTS-CLÉS: allégorie, cesteur, nation.

REFERÊNCIAS BIBLIOGRÁFICAS

ANDERSON, Benedict. Comunidades imaginadas: reflexiones sobre el origen y la difusión del nacionalismo. México: Fondo de Cultura Econômica, 1993.

ARAÚJ0, Jorge de Souza. O perfil do leitor colonial. Salvador: UFBa; Il héus: UESC, 1999.

BHABHA, Homi. O local da cultura. Belo Horizonte: Ed. UFMG, 1998.

CASCUDO, Luís da Câmara. Cinco livros do povo: introdução ao estudo da novelística no Brasil. Rio de Janeiro: José 01ympio, 1953.

- Literatura oral no Brasil. 2. ed. Rio de Janeiro: José 0lympio; Brasillia: INL 1978. (Documentos Brasileiros, 186)

CÓdICE COSTA MATOSO. Belo Horizonte: Fundação João Pinheiro, Centro de Estudos Históricos e Culturais, 1999. (Mineiriana).

DRUMMOND, Maria Francelina Silami Ibrahim. Brasil peregrino na alegoria de Nuno Marques Pereira. 2000. Tese (Doutorado em Literatura Comparada) - Faculdade de Letras da UFMG, Belo Horizonte.

LIMA VAZ, Henrique Cláudio. Escritos de filosofia II: ética e cultura. São Paulo: Loyola, 1988.

PEREIRA, Nuno Marques. Compêndio narrativo do peregrino da América. Rio de Janeiro: ABL, 1988, 2 v. In: SUSSEKIND, Flora. O Brasil não é longe daqui: o narrador, a viagem. São Paulo: Companhia das Letras, 1990 